\title{
THE LEGALITY OF "PEACEFUL COERCION" IN LABOR DISPUTES *
}

\section{Bernard EskIN $\dagger$}

The use of violence, fraud, and other "non-peaceful" tactics is often a ground for judicial interference in labor disputes. It may not be fully realized that this is not the only reason which moves courts to intervene. Numerous decisions have turned upon issues raised by labor's resort to methods which, though coercive in that they bring economic loss upon employers who resist, are nevertheless "peaceful", in the sense that they involve no violent or patently unsocial invasions of recognized interests. It is to the consideration of these issues that the present study is addressed.

The principal legal questions involved in the cases dealing with labor activity ${ }^{1}$ are the outgrowth of a social condition-the fact that two classes in society, employers and employees, have antagonistic economic interests. The workman's desire for higher wages, shorter hours, and security of employment is opposed to the employer's interest in gaining profits by maximum production at minimum cost. A secondary phase of this conflict is manifested in the efforts of employers to deal with workmen individually, as opposed to labor's endeavor to utilize and perfect the device of collective action through organized combinations. Under our present economic and legal arrangement, the resolution of the conflict is left largely to the opposing parties themselves. The ostensible function of the law is not to settle or force settlement of the ultimate questions involved; it is simply to set limits within which the parties may use their own powers of persuasion and compulsion to gain their respective ends.

Judicial conflict centers chiefly about the use by workers of various devices of economic pressure to compel employers to accede to their demands. When such pressure is exerted, either by causing the cessation of labor or the withdrawal of patronage, the employer and sometimes others suffer economic loss unless they yield. Freedom from such injury is the legal "interest" protected when judicial action is taken against workers' activities. Courts, generally, in their treatment of these cases, begin with the assumption that

* The writer wishes to acknowledge his debt to Professor A. H. Frey, of the University of Pennsylvania Law School, for the valuable aid and advice he has given in the preparation of this paper.

$\dagger$ B.S. in Econ., 1932, LL. B., 1935, LL. M., 1936, University of Pennsylvania; member of the Philadelphia bar.

I. The term "labor action" or "labor activity", as used in this paper, denotes acts or conduct by workmen, or by persons acting in behalf of workmen, which cause or are directed toward the causation of damage to an employer or other person involved in a labor controversy. This includes activity often designated by such words as "strike", "boycott" and "picketing". 
the mere invasion of this interest is wrongful unless "justified"; that presumptively the plaintiff is entitled to relief on the showing that he has been or will be damaged by the concerted activity of the defendants. ${ }^{2}$ Under this "prima facie" theory the "justification" which the defendants must establish usually finds its basis in the self-interest of the workmen in advancing their economic position. ${ }^{3}$ If the activity is not calculated to further this end, the damage inflicted thereby is not "justified". The converse of this proposition, however, is not true: the activity is not always justified merely because the end sought is the improvement of the workers' status. Other and more particular facts in a case may provide the basis of decision. In the present discussion an effort is made to break up the cases into the facts which comprise them and which appear significant in the decisions, and to determine what legal effect is or ought to be given to each type of factual situation.

A great difficulty encountered in such a study lies in the factual complexity of nearly all cases of labor controversy. Legally significant facts are seldom found singly in the cases. Moreover, the courts' opinions too infrequently isolate the troublesome facts and deal with each separately. In a single case there may be activity by an "outside" union, inducing breaches of contract, directed toward the establishment of a closed shop, accompanied by violence and fraud. 4 In such a case there are half a dozen fact situations involved, each of which presents a separate problem, which different courts have resolved in different ways. Nevertheless, for purposes of study, the various factors may be classified separately and the cases which stress one factor or another grouped accordingly. The factual situations which have given rise to the greatest measure of judicial controversy may be classified as follows:

I. The type of economic pressure exerted, such as cessation of work or withdrawal of patronage.

2. The nature of the particular concession desired of the employer by the workmen, such as higher wages or a closed shop.

2. See Dorchy v. Kansas, 272 U. S. 306, 3Ir (1926) ; United Chain Theatres v. Philade1phia Motion Picture Operators' Union, 50 F. (2d) I89, x9I (E. D. Pa. I93I); Holmes, Privilege, Malice, and Intent (I894) 8 HARv. L. REv. I.

3. Cf. Smith, Crucial Issues in Labor Litigation (I907) 20 HARv. L. REv. 253, 256-8. In cases involving competition among entrepreneurs a similar "business" interest provides the basis for immunity from judicial restraint upon activity causing economic damage. Mogul S. S. Co. v. McGregor, [I8g2] A. C. 25. And this is true even where the damage is caused by a concerted refusal to deal by a combination of tradesmen. Bohn Mfg. Co. v. Hollis, 54 Minn. 223, 55 N. W. rII9 (I893); Annold v. Burgess, 24I App. Div. 364, 272 N. Y. Supp. 534 (Ist Dep't, 1934). On the other hand, if the injurious activity is not motivated by a desire to establish or advance a bona fide competing business, the injured person has a right of action, even though ordinary methods of business competition are used. Boggs v. DuncanShell Co., I63 Iowa 106, 143 N. W. 482 (I913); Tuttle v. Buck, I07 Minn. I45, Irg N. W. 946 (1909).

4. See Hitchman Coal \& Coke Co. v. Mitchell, 245 U. S. 229 (I917). 
3. The fact that the labor activity will cause, or is deliberately directed toward, the breach of some contract.

4. The fact that the labor activity is instigated or carried on by persons who are not employees of plaintiff, and have not been directed by the employees to act for them.

5. The relation of the plaintiff to the controversy, whether employer, employee, or third party. ${ }^{5}$

\section{The Type of Economic Pressure Exerted}

\section{Concerted Cessation of Work}

Almost invariably a concerted cessation of work is not the spontaneous or self-instigated action of workmen, but is the result of union action, usually through orders of union officials and representatives. Only a few cases have been found which, with the most liberal interpretation of the facts, can be said to be instances of walkouts or threats thereof without union sponsorship. In these cases there is an indication of judicial recognition that if this is the sole activity of the workmen it is not unlawful, regardless of the reason for the action. This conclusion has been reached both where the suit was for damages ${ }^{6}$ and for an injunction. ${ }^{7}$ Another decision denying an injunction was based partly on the ground that a decree against quitting work would amount to an affirmative order to work, an order which a court of equity ought not to make. ${ }^{8}$ There is some contrary authority: while no case has been found in which an injunction was granted against a voluntary walkout, damages have been awarded against workmen participating in the action, ${ }^{9}$ and such workmen have been held criminally liable. ${ }^{10}$

It is difficult to perceive any reason for distinguishing between cessation of work by the workers on their own initiative and that instituted by union

5. A number of minor or seeming factors may be listed: (I) The fact that the economic pressure is accompanied by conduct which the court considers anti-social without regard to a labor dispute, such as violence or fraud. Levy \& Devaney, Inc. v. International Pocketbook Workers' Union, II4 Conn. 3r9, I58 Atl. 795 (I933) ; Nann v. Raimist, 255 N. Y. 307, I74 N. E. 690 (193I). (2) The good faith of the workmen or their leaders in seeking the end they profess. Cf. Eschman v. Huebner, 226 Ill. App. 537 (I922) ; Beckerman v. Bakery \& Confectionery Workers' Union, 28 Ohio N. P. (N. s.) 550 (C. P. I93I). (3) The fact that labor action tends to interfere with interstate commerce. See International Brotherhood v. Western Union Tel. Co., 6 F. (2d) 444,445 (C. C. A. 7th, I925). (4) Statutes bearing on the subject, such as anti-trust acts, statutes limiting the use of the injunction, and laws expressly permitting certain types of activity. (5) The fact that the labor action is carried on by a combination. But this can hardly be regarded as a factor of decision since it occurs in virtually every case.

6. Clemmitt v. Watson, 14 Ind. App. 38, 42 N. E. 367 (1895).

7. Rutan Co. v. Local Union, 97 N. J. Eq. 77, 128 At1. 622 (1925).

8. Lundoff-Bicknell Co. v. Smith, 24 Ohio App. 294, I56 N. E. 243 (1927). It may safely be said that this is the position of most courts.

9. Bausbach v. Reiff, 244 Pa. 559, 9 I Atl. 224 (1914) (suit brought by discharged workman against fellow-workers); cf. Mapstrick v. Ramge, 9 Neb. 390 (I879) (workmen quit leaving unfinished goods).

Io. State v. Donaldson, 32 N. J. L. I5I (I867). 
action. In the latter case the union leaders and agents, even if not themselves employees, are the chosen representatives of the workmen and cannot in any realistic sense be regarded as "outsiders" who "intermeddle" with the employer's relations with his employees. When workers quit on order of the union they simply respond to a command which they have previously, in joining the union, agreed to obey.

A priori a case might be made for the position that more freedom should be accorded to workmen in simply stopping work and to unions in aiding the stoppage of work than in engaging in more "affirmative" activity, such as picketing. In simply withdrawing their labor workmen directly involve no one but themselves and the employer, whereas in picketing and in inducing third parties to withdraw support from the employer the workers widen the field of battle and draw into it combatants who are disinterested or only indirectly interested in the outcome. Moreover the mere quitting of work is the correlative of the employer's action in discharging a worker, which under the existing law he may do for any or no reason, in the absence of contract obligations to the contrary. ${ }^{11}$ The workers' privilege in the one case should be as extensive as the employer's in the other.

It may thus be argued that when workmen merely quit work, even though it be at the union's order, the courts should not inquire into their reasons or motives for doing so, although such an inquiry may be appropriate when the labor activity goes beyond that. However, virtually no support can be found for such a position in the cases; no court expressly takes such a stand. Cases may be found in which "picketing" but not "striking" was enjoined, but generally in such cases the complainant's prayer was for an injunction against picketing only. ${ }^{12}$ On the other hand there are many cases in which the only activity involved was a cessation of work by union direction, and an injunction was issued against union representatives restraining activity in support of the withdrawal of labor either on the ground that the purpose was "unlawful" 13 or because the activity constituted or tended toward a breach of contract. ${ }^{14}$

II. It has been held that an employer may discharge employees, though the reason is that they belong to a union, Bayer v. Western Union Tel. Co., I24 Fed. 246 (E. D. Mo. I903); or that they refuse to join a particular union, Mills v. United States Printing Co., 99 App. Div. 605 , 91 N. Y. Supp. I85 (2d Dep't, I904). Moreover, an employer cannot constitutionally be punished criminally for discharging a worker because of union affiliation. Adair v. United States, 208 U. S. I6I (I908). See Sayre, Labor and the Courts (1930) 39 YAle L. J. 682, 696.

12. Elkind \& Sons, Inc. v. Retail Clerks Ass'n, II4 N. J. Eq. 586, I69 At1. 494 (I933); Wasilewski v. Bakers' Union, II8 N. J. Eq. 349, I79 At1. 284 (I935); Cooks' Union v. Papageorge, 230 S. W. 1086 (Tex. Civ. App. I92I).

I3. See the Massachusetts cases cited infra notes 45, 46; Standard Engraving Co. v. Volz, 200 App. Div. 758, I93 N. Y. Supp. 83I (Ist Dep't, I922) ; Erdmann v. Mitchell, 207 Pa. 79, 56 At1. 327 (1903); Larkin v. Long, [19I5] A. C. 814.

14. See cases cited infra note 87. 


\section{Labor Action Involving Third Parties}

Significant in numerous cases in which the propriety of labor action is brought into question is the fact that the activity involves persons who may be said to have no direct interest in the struggle-who are neither the employer nor employees, present or prospective. Such persons, usually customers or suppliers of the employer, are brought into the conflict through the efforts of the complaining workmen. Many decisions against labor may be attributed to the presence of this factor. The principal characteristic of the labor action here involved is that it seeks to procure third parties to exert pressure upon the employer, as contrasted with the other cases where the pressure is exerted directly upon the employer by the workers. The element in this type of activity which the courts consider most material is not the type of pressure brought against the employer by the third persons, but the method by which the latter are induced to take action. From this point of view these cases may be grouped into two classes: (a) where the third persons are induced by "non-coercive" means, i. e., argument, persuasion, or appeal to the sense of fairness; (b) where economic pressure is exerted against the third parties. (A possible third type, where violence rather than mere economic coercion is used, is not discussed.)

\section{a. Persuasion and Similar Means}

A common method used in the first type of action is "picketing," i. e., patrolling the employer's place of business and notifying the public by banners, placards, etc., of the existence of the dispute and requesting withdrawal of patronage. ${ }^{15}$ Generally such activity is not of itself condemned by the courts, ${ }^{16}$ but in a few jurisdictions it is not permitted. ${ }^{17}$

Other methods are those which seek to reach the employer's patrons by circulars, letters, personal solicitation, and the publication of the employer's name in "unfair lists". Where these methods are the only ones used, the action has been permitted. ${ }^{18}$ In some cases persuasion was coupled with

I5. Such methods are, of course, effective only when the business is such as relies directly upon the consuming public for patronage. See Note (r933) 33 CoL. L. REv. II88.

I6. Numerous cases permit picketing to induce withdrawal of patronage. E. g., Steffes v. Motion Picture Operators' Union, I36 Minn. 200, I6I N. W. 524 (IgI7); Empire Theatre v. Cloke, 53 Mont. 183, I63 Pac. I07 (Ig17) ; Exchange Bakery v. Rifkin, 245 N. Y. 260, I57 N. E. I30 (I927); Clark Lunch Co. v. Cleveland Waiters' Local Union, 22 Ohio App. 265 , I54 N. E. 362 (I926). I7I.

I7. See Hellerstein, Picketing Legislation and the Courts (1932) Io N. C. L. Rev. I58,

18. United Chain Theatres v. Philadelphia Motion Picture Operators' Union, 5o F. (2d) I89 (E. D. Pa. I93I) (letters to patrons); Marx Clothing Co. v. Watson, I68 Mo. I33, 67 S. W. 391 (I902) (circulars and personal solicitation); Blumenthal v. Feintuch, I53 Misc. 40, 273 N. Y. Supp. 660 (Sup. Ct. I934) ("appeal to public") ; Zaat v. Building Trades Council, I72 Wash. 445, 20 P. (2d) 589 (I933) (unfair list). Contra: Martin v. McFall, 65 N. J. Eq. 9I, 55 Atl. 465 (r903) ("inducing other persons not to deal").

The same result has been reached in cases involving the use of similar methods by combinations of entrepreneurs against competitors in advancing their business interests. Ulery $v$. 
"coercion" in the form of economic pressure, and an injunction was granted against all activity, no allowance being made for the use of persuasion alone. ${ }^{19}$

\section{b. Economic Pressure}

Economic pressure may be exerted upon the employer's patrons in two ways: (I) the workmen, through their organization, may withdraw their labor from the patrons or induce other workers to withdraw; (2) the workmen may withdraw patronage from the patrons and induce others to do likewise. It is doubtful whether there is any reason for distinguishing between these two types of activity for legal purposes. Both are devices for bringing pressure to bear upon third parties in order ultimately to compel the employer to comply with the demands of the workers. It is a fact, however, that while the great majority of courts condemn all combinations to exert economic pressure upon third persons, the withdrawal of labor is permitted by a larger minority than is the withdrawal of patronage. The two types of activity will be considered separately.

\section{(I) Withdrawal of Labor}

The withdrawal of labor from a patron may result from activity by a single union or group of unions of the same craft or industry, or by unions less closely related. This distinction has been alluded to in several cases, ${ }^{20}$ and it seems to be the basis for reconciliation of the two leading New York cases, Bossert v. Dhuy ${ }^{21}$ and Auburn Draying Co. v. Wardell. ${ }^{22}$ In the former case both the complaint against the employer and the action against the patron were instituted by a union representing one type of workers (carpenters), while in the Auburn case the workers involved in the threatened action against the patrons were of crafts different from that of the workers of the objectionable employer. There is doubtless some basis for this distinction in the desire of courts to limit the labor struggle to as narrow a field as possible. However, the cases in other jurisdictions do not reveal any tendency to follow the line of distinction taken by the New York decisions. In the great majority of cases involving activity to cause the stoppage of

Chicago Livestock Exchange, 54 Ill. App. 233 (I894) ; Park \& Sons v. National Druggists' Ass'n, I75 N. Y, I, 67 N. E. I36 (1903); Wolfenstein v. Fashion Originators' Guild, 244 App. Div. 656, 280 N. Y. Supp. 36I (Ist Dep't, I935). Contra: Olive v. Van Patten, 7 Tex. Civ. App. 630,25 S. W. 428 (1894) ; Hawarden v. Youghiogheny Coal \& L. Co., III Wis. 545,87 N. W. 472 (IgOI).

I9. American Fed. of Labor v. Bucks Stove \& Range Co., 33 App. D. C. 83 (1909) ; My Maryland Lodge v. Adt, I00 Md. 238, 59 Atl. 72I (I905); Thomson Machine Co. v. Brown, 89 N. J. Eq. 326, 104 Atl. I29 (I9r8).

20. See dissenting opinion of Brandeis, J., in Bedford Cut Stone Co. v. Stone Cutters' Ass'n, 274 U. S. 37, 63 (1927) ; Berman, LABOR AND the SHERMAN ACT (I930) 253 et seq. 2I. 221 N. Y. 342 , II T N. E. 582 (I9I7).

22. 227 N. Y. I, 124 N. E. 97 (19I9). 
work in the plants of patrons by workers of the same craft as the original complaining employees, the action was enjoined, ${ }^{23}$ at least partly because of its indirection. Surprisingly enough there is a more even split in the cases in which the employees of patrons were less closely related by economic ties to the workers with the original grievance. ${ }^{24}$

\section{(2) Withdrawal of Patronage from Patrons}

Instead of causing a withdrawal of labor from customers, or threatening to do so, combinations of workmen may exert pressure by causing or threatening to cause ai withdrawal of the customers' patrons. The custom upon which a patron of the employer depends may be that of the workmen themselves or other workmen acting in sympathy with the former, or that of persons who may be described generally as the trading and consuming public. In most of the cases found on this subject the patronage withdrawn was that of workmen of diverse crafts and callings, generally members of large federations or councils comprising numerous unions. In one case in which only members of the same craft were involved the labor action was permitted. ${ }^{25}$ Among the cases involving different crafts and industries, in only one was the action permitted, ${ }^{26}$ whereas numerous decisions on these facts hold against the laborers. ${ }^{27}$ No case has been found which allowed

23. E. g., O'Brien v. Fackenthal, 5 F. (2d) 389 (C. C. A. 6th, 1925) ; Armstrong Cork \& Insulation Co. v. Walsh, 276 Mass. 263 , I77 N. E. 2 (I93I); Thomson Machine Co. v. Brown, 89 N. J. Eq. 326, I04 Atl. I29 (I9I8) ; Purvis v. Local No. 500, United Brotherhood of Carpenters \& Joiners, 2I4 Pa. 348, 63 Atl. 585 (Ig06) ; cf. Bedford Cut Stone Co. v. Stone Cutters' Ass'n, 274 U. S. 37 (I927) (decided under Sherman Act). Contra: Gill Engraving Co. v. Doerr, 2I4 Fed. IIr (S. D. N. Y. I9I4) ; Meier v. Speer, 96 Ark. 6r8, I32 S. W. 988 (I910) ; Grant Construction Co. v. St. Paul Building Trades Council, I36 Minn. I67, I6I N. W. 520 (IgI7).

24. E. g., activity by affiliated unions of different crafts in same industry or type of work enjoined at suit of employer: International Brotherhood v. Western Union Tel. Co., 6 F. (2d) 444 (C. C. A. 7th, I925) (affiliated building trades unions); Blandford v. Duthie, I47 Md. 388, I28 Atl. I38 (I925) (same); Patterson \& Co. v. Building Trades Council, II Pa. Dist. 500 (Ig02) (same); enjoined at suit of patron: Buyer v. Guillan, 27x Fed. 65 (C. C. A. 2d, I92r) (affiliated transportation unions; decided under Sherman Act). Contra: injunction denied in suit by employer: Parkinson Co. v. Building Trades Council, 154 Cal. 58r, 98 Pac. ro27 (rgo8) (affiliated building trades unions); Cohn \& Roth Electric Co. v. Bricklayers' Union, 92 Conn. I6I, Ior Atl. 659 (I9I7) (same) ; Reardon v. Caton, I89 App. Div. 50r, 178 N. Y. Supp. 7I3 (2d Dep't, r9I9) (affiliated transportation unions).

Activity by workmen of unrelated crafts enjoined at suit of employer: Duplex Printing Press Co. v. Deering, 254 U. S. 443 (Ig2I) (workmen engaged in selling, transporting, installing, and operating printing presses; decided under Sherman Act); Auburn Draying Co.v. Wardell, 227 N. Y. I, I24 N. E. 97 (I9T9) (employees in community generally). Contra: Willson \& Adams Co. v. Pearce, 240 App. Div. 7I8, 265 N. Y. Supp. 624 (2d Dep't, I933) (building trades workers and teamsters; Auburn case mentioned but not satisfactorily distinguished).

25. Pierce v. Stablemen's Union, I56 Cal. 70, ro3 Pac. 324 (I909).

26. Lindsay \& Co. v. Montana Fed. of Labor, 37 Mont. 264, 96 Pac. I27 (Ig08).

27. E. g., Rocky Mt. Bell Tel. Co. v. Montana Fed. of Labor, I56 Fed. 809 (D. Mont. I907); Wilson v. Hey, 232 Ill. 389, 83 N. E. 928 (I908) ; Beck v. Railway Teamsters' Union, II8 Mich. 497, 77 N. W. I3 (I898); Barr v. Essex Trades Council, 53 N. J. Eq. Ior, 30 At1. 88I (I894). 
the workmen to solicit the aid of non-workmen, ${ }^{28}$ while a number of cases have condemned such action. ${ }^{29}$ In short the overwhelming weight of judicial opinion is set against the use of methods of economic pressure upon patrons and especially against the methods involved in the cessation of business dealings of such patrons with other persons.

The opinions in cases dealing with activity affecting third persons are unusually bare of reasoning based upon economic and social considerations. In view of the large number of decisions opposed to such activity one would expect at least an attempt on the part of courts to justify the result on some rational ground connected with justice and expediency. Why, for example, is it "per se" lawful for workmen to quit the service of an employer (a proposition to which all modern courts verbally adhere) and yet "per se" unlawful for them to cease working for a customer of the employer?" ?hy $^{30}$ is it permissible to persuade the customers of the employer to withdraw their patronage by argument and appeals to sympathy, and yet not permissible to use methods of economic pressure upon the customers to achieve the same objective? Of course the facts are different in these types of cases; but why should these factual variations require a difference in legal result? Nowhere in the cases is there anything approaching a convincing reply to these questions, nor an adequate presentation of reasons for condemning the so-called "secondary boycott".

Superficial and question-begging "reasons" have been advanced. An entrepreneur has a "right to a free market", it is asserted." But if "free" means without interference by pressure on customers, then the proposition patently assumes the point in issue; if it means without "unreasonable" restraint, then the question still remains, why is the "boycott" unreasonable? A typical example of absurd reasoning is found in Gray v. Building Trades Council: ${ }^{32}$ "In restraining boycotts, the authorities proceed on the theory that they are unlawful interferences with property rights." There is no intimation in the opinion as to why the interference is unlawful.

A somewhat more substantial basis of decision has been intimated, though not developed with any fullness, in a few cases. It is that a "boycott", involving pressure upon third persons disinterested in the dispute and

28. But cf. Zaat v. Building Trades Council, 172 Wash. 445, 20 P. (2d) 589 (I933) (court, in denying injunction to employer, intimated that it would make no difference if pressure were brought to bear against a patron by inducing the public to withdraw patronage from the latter).

29. Loewe v. Lawlor, 208 U. S. 274 (1908) (decided under Sherman Act) ; My Maryland Lodge v. Adt, xoo Md. 238, 59 Atl. 721 (I905); Fink \& Son v. Butchers' Únion, 84 N. J. Eq. 638, 95 Atl. I82 (I9I5); $c f$. Commercial Cleaning Co. v. Awerkin, I38 Misc. 512, 240 N. Y. Supp. 797 (Sup. Ct. I930) ; Parker Paint \& Wall Paper Co. v. Local Union, 87 W. Va. $63 \mathrm{I}$, 105 S. E. 9II (I92I) (both cases of picketing against customers of the employer).

30. See LAddere, Boycotts ANd the Labor Struggle (19I3) I87, 212, which raises the same question.

3r. See Booth v. Burgess, 72 N. J. Eq. I8r, 197, 65 Atl. 226, 233 (1906).

32. 91 Minn. I7I, I82, 97 N. W. 663, 667 (I903). 
perhaps including businesses of more remote parties in its attack, tends to affect the business of a whole community or a large part thereof. ${ }^{33}$ This argument apparently proceeds upon the factual assumption that a "strike" has less tendency to disrupt the business of the community as a whole than activity which involves pressure upon third parties. The writer knows of no statistical study which supports this conclusion and no court which employs this type of argument relies upon any. In the absence of some evidence of a tendency of third-party action to injure the public welfare more seriously than direct action against the employer, it would seem that a court is not justified in distinguishing the two types of activity on the assumption that such is the fact. ${ }^{34}$

While the great weight of authority condemns the use of pressure against third parties by laborers, the judicial attitude is by no means the same in the cases involving the same type of economic coercion exerted by entrepreneurs against competitors. When business men, singly or in combination, seek to cause a cessation of business dealings between a competitor and his patrons and suppliers by the exertion of economic pressure upon the latter, the weight of authority allows the activity, provided it is carried on by business men to advance their trade interests. ${ }^{35}$ It is difficult to reconcile this result with the numerous decisions condemning the use of similar pressure by combinations of workmen. In both types of cases the moving parties seek to advance or protect their respective economic interests. In both the plaintiff, who has a conflicting interest, is economically injured. Is the desire of an entrepreneur to strengthen and advance his business a matter in which society has a greater stake than is the desire of workmen to improve their economic condition, so that the first type of interest might justify conduct which is not justified by the latter? If the advancement of both interests is equally favored by society, can it be said that the entrepreneurs need such a device as the "pressure boycott", in order to achieve their aims, more than workmen need it? Whatever may be said of the relative social values of the two interests, the latter question surely deserves a negative

33. See Fink \& Son v. Butchers' Union, 84 N. J. Eq. 638, 642, 95 Atl. 182, I84 (1915); Wilson v. Hey, 232 Ill. 389, 398, 83 N. E. 928, 930 (1908).

34. Cf. Berman, Labor and the Sherman Act (I930) 264. The author reaches the conclusion that the "secondary boycott" is a reasonable means of attaining the ends of labor and should be permitted under the Sherman Act.

35. Montgomery Ward Co. v. South Dakota Retail Ass'n, I50 Fed. 4I3 (D. S. D. 1907) ; Rosenau v. Empire Circuit Co., I3I App. Div. 429, II5 N. Y. Supp. 5 II (4th Dep't, I909) ; Macauley v. Tierney, I9 R. I. 255, 33 Atl. I (I895) ; Celli v. Galveston Brewing Co., 227 S. W. 94I (Tex. Comm. App. I92I); Sorrell v. Smith, [1925] A. C. 700; cf. Owen v. Westwood Lumber Co., 22 F. (2d) 992 (D. Ore. I927) ; Dagostino v. Rogers, 68 Pa. Super. 284 (I9I7) (latter two cases involved compulsion by employers operating "company stores" to force employees by threat of discharge to refrain from patronizing competing stores). Contra: Purington v. Hinchcliff, 2I9 IIl. I59, 76 N. E. 47 (1905); Walker v. Fort Worth Insurance Underwriters' Ass'n, 79 S. W. (2d) 66I (Tex. Civ. App. I934). 
answer. Entrepreneurs, even with no association at all, are able to care for themselves under normal circumstances of business competition, with little or no handicap attributable to the nature of their economic position. This cannot be said of laborers. A single workman is virtually at the mercy of his employer; and even in combination workers are at a decided disadvantage unless they can make use of weapons of collective action. For business men, combination may be a great advantage in furthering their economic interests; for workmen, combination is a necessity. A legal doctrine which permitted a certain type of collective action by workmen against employers and denied its use to entrepreneurs inter se would be plausible. But the opposite result is indefensible. At the very least courts which permit pressure by entrepreneurs upon patrons of their competitors should allow the same type of action by workmen.

\section{The Nature of the Concession Desired}

While the ultimate end of labor activity is generally the improvement of the workers' status, this end is invariably sought to be achieved by gaining some specific concession from the employer. The nature of this immediate objective is often an important factor in moving a court to condemn or condone the activity. The principal concessions which have been involved in judicial controversy will be discussed. ${ }^{36}$

\section{r. Wages and Hours}

Some of the earliest cases dealing with labor disputes concern the lawfulness of concerted action by laborers to win an increase in wages. That such action was held to be punishable as a crime ${ }^{\mathbf{3 7}}$ is an interesting commentary on the social and economic philosophy of courts of a bygone day.

36. A number of other types of labor demands have arisen, though infrequently, in the cases. In the decisions involving the following demands the labor activity was condemned: (I) That an employer join an employers' association. Coons v. Chrystie, 24 Misc. 296, 53 N. Y. Supp. 668 (Sup. Ct. I898) ; Larkin v. Long, [IgI5] A. C. 814. Contra: Sheehan v. Levy, 238 S. W. 900 (Tex. Comm. App. I922). (2) That certain employers be ejected from an employers' association. Beckerman v. Bakery \& Confectionery Workers' Union, 28 Ohio N. P. (N. S.) 550 (C. P. I93I) (this was one of several grounds of the decision). (3) That the employer adhere to certain prices for his products fixed by the union. Standard Engraving Co. v. Volz, 200 App. Div. 758, I93 N. Y. Supp. 83I (Ist Dep't, 1922). (4) That the employer refrain from doing certain work usually done by members of the union. Campbell v. Motion Picture Operators' Union, I5I Minn. 220, I86 N. W. 78I (1922) ; Hughes v. Kansas City Motion Picture Operators' Union, 282 Mo. 304, $221 \mathrm{~S}$. W. 95 (1920). Contra: Zaat v. Building Trades Council, 172 Wash. 445, 20 P. (2d) 589 (1933). (5) That the employer refrain from using men-displacing machinery. Hopkins v. Oxley Stave Co., 83 Fed. 912 (C. C. A. 8th, I897). But cf. Bayer v. Brotherhood of Painters, I08 N. J. Eq. 257, I54 Atl. 759 (I93I). (6) That the employer agree to have disputes settled by the union council. Reynolds v. Davis, I98 Mass. 294, 84 N. E. 457 (I908). (7) That the employer act in a way which would be criminal. Toledo, A. A. \& N. M. Ry. v. Pennsylvania Co., 54 Fed. 730 (N. D. Ohio, I893).

37. Rex v. Hammond \& Webb, 2 Esp. 719 (Nisi Prius, 1799) ; Philadelphia Cordwainers' Case, Mayor's Ct., Phila. I806, reported in SAYRE, Cases on Labor Law (I923) 99. 
The modern cases reveal a practical unanimity of opinion that the mere fact that the labor action is directed toward an increase in wages does not move the court to interfere. ${ }^{38}$ The same result is reached in the case of action to gain a decrease in hours of work. ${ }^{39}$

There is some judicial conflict in the special case of a demand for wage scales prevalent in the locality of an out-of-town contractor when such scales are higher than those in the locality where the work is being done. The weight of authority holds that such a demand does not render the labor action unlawful. ${ }^{40}$

\section{Concessions Tending to Strengthen Organization}

\section{a. The Closed Shop}

The efforts of workmen to secure a closed shop ${ }^{41}$ furnish the material for most of the cases involving the nature of the concession desired. In a majority of the jurisdictions in which the question has been raised the courts have upheld the action of the workmen, ${ }^{42}$ even though it involved procuring the discharge of other workmen, ${ }^{43}$ and even though in the latter case there were no facts to show that the union was not unfairly excluding the non-union workmen. ${ }^{44}$ In many of the cases condemning the labor action the fact that the concession desired was a closed shop furnished only one of the grounds of decision, there being other conduct or circumstances

38. American Steel Foundries v. Tri-City Central Trades Council, 257 U. S. I84 (I92r) (particular acts enjoined but "peaceful" action permitted) ; Karges Furniture Co.. v. Amalgamated Woodworkers' Union, I65 Ind. 42r, 75 N. E. 877 (1905); Saulsberry y. Coopers' Union, $147 \mathrm{Ky} .170,143 \mathrm{~S}$. W. Ior8 (1912); see Jefferson \& Indiana Coal Co. v. Marks, 287 Pa. I7I, I77, I34 Atl. 430, 432 (I926).

39. Reardon v. Caton, 189 App. Div. 501, 178 N. Y. Supp. 7r3 (2d Dep't, 1919) ; Everett Waddey Co. v. Richmond Typographical Union, Io5 Va. I88, 53 S. E. 273 (I906).

40. Barker Painting Co. v. Local Union, 34 F. (2d) 3 (C. C. A. 3d, 1929); New Jersey Painting Co. v. Local Union, 96 N. J. Eq. 632, I26 At1. 399 (I924). Contra: Hass, Inc. v. Local Union, 300 Fed. 894 (D. Conn. I924).

41. The "closed shop" should be differentiated from "union recognition". In the former situation only union men are employed, while the latter denotes simply acceptance by the employer of the union as the bargaining agency of some or all of the workers, who may or may not include non-union men.

42. Pierce v. Stablemen's Union, I56 Cal. 70, ro3 Pac. 324 (Igog); Cohn \& Roth Electric Co. v. Bricklayers' Union, 92 Conn. I6I, IOI Atl. 659 (I9I7) ; Fenske Bros. v. Upholsterers' Union, 358 I11. 239, I93 N. E. I12 (1934); Scofes v. Helmar, 205 Ind. 596, I87 N. E. 662 (1933); Wise Shoe Co. v. Lowenthal, 266 N. Y. 264, I94 N. E. 749 (I935); cf. Bayonne Textile Corp. v. American Fed. of Silk Workers, I I6 N. J. Eq. I46, r72 At1. 55I (I934) (injunction granted against violence only; no point made of closed shop factor).

43. Parkinson Co. v. Building Trades Council, I54 Cal. 581, 98 Pac. I027 (I908); Wunch v. Shankland, 59 App. Div. 482, 69 N. Y. Supp. 349 (4th Dep't, I901); White v. Riley, [I92I] I Ch. I.

44. Kemp v. Division 24I, 255 Ill. 213, 99 N. E. 389 (I9I2) ; National Protective Ass'n of Steam Fitters v. Cumming, 170 N. Y. 315, 63 N. E. 369 (1902) ; Clark Lunch Co. v. Cleveland Waiters' Local Union, 22 Ohio App. 265, I54 N. E. 362 (Ig26) ; Roddy v. United Mine Workers, 4I Okla. 621, 139 Pac. 126 (I914). 
sufficiently obnoxious to the court to supply additional grounds. ${ }^{45}$ In relatively few cases has this fact been the sole or predominant factor. ${ }^{4 \mathrm{~B}}$

Two reasons worthy of note have been advanced by courts which condemn such labor action. It is stated that the law condones labor activity, though it injures another, if the "immediate purpose" of the workmen is to further their economic interest; but if the end of benefit to the workmen is merely "remote" the direct injury to another cannot be justified (under the "prima facie" theory previously discussed). ${ }^{47}$ The closed shop, these courts argue, is not itself beneficial to the employees, but only aids in strengthening their organization and placing them in a better position to demand benefits in the future. In thus failing to demonstrate an "immediate" benefit, those who seek a closed shop fail to make a case of justification for their action. It would seem a valid criticism of this argument that it places far too much emphasis on the time element, and not enough on the actual degree of benefit gained by the workmen..,8 If, as most courts profess, the advancement of the economic interest of the workmen is the basis of their privilege to take damaging action against the employer, it would seem that the only relevant inquiry is as to how materially particular action is likely to advance such interest, irrespective of whether benefit results immediately or in the future. No court has attempted to attack the closed shop and union representation by showing that they are not really advantageous to the employees. On the other hand, enlightened and informed judges have recognized that a strong union is a vital aid in furthering the laborers' economic interests. ${ }^{49}$

A much more substantial argument is that the closed shop gives the labor union a monopoly of available labor in a given field and concentrates a drastic power for evil in the hands of those who control the union. ${ }^{50}$ Since

45. E. g., Barnes v. Berry, I56 Fed. 72 (S. D. Ohio, I907) (also involved breach of contract) ; Sarros v. Nouris, I38 Atl. 607 (Del. Ch. 1927) (picket and boycott) ; Hotel News Co. v. Lowenthal, 243 Mass. 3I7, I37 N. E. 534 (Ig22) (false statements) ; Wasilewski v. Bakers' Union, II8 N. J. Eq. 349, I79 At1. 284 (I935) (outside union); Freed v. Doe, I54 Misc. 644,278 N. Y. Supp. 68 (Sup. Ct. I935) (violence) ; Cooks' Union v. Papageorge, 230 S. W. 1086 (Tex. Civ. App. 192I).

46. Bausch Machine Co. v. Hill, 23I Mass. 30, I20 N. E. I88 (I9I8) ; United States Heater Co. v. Iron Molders' Union, I29 Mich. 354, 88 N. W. 889 (I902) ; White Mt. Co. v. Murphy, 78 N. H. 398, Ior Atl. 357 (I9I7) ; Elkind \& Sons v. Retail Clerks' Ass'n, II4 N. J. Eq. 586, 169 At1. 494 (1933). In this category may also be included cases in which suit was brought by employees who suffered discharge through the labor action for a closed shop. Fairbanks v. McDonald, 2I9 Mass. 291, I06 N. E. I000 (Igr4); Curran v. Galen, I52 N. Y. 33, 46 N. E. 297 (I897); Erdmann v. Mitchell, 207 Pa. 79, 56 Atl. 327 (I903).

47. See Davis Machine Co. v. Robinson, $4 \mathrm{I}$ Misc. 329, 334, 49 N. Y. Supp. 837, 840 (Sup. Ct. 1903) ; Moreland Theatres Corp. v. Portland Motion Picture Operators' Union, I 40 Ore. $35,44,12$ P. (2d) 333,337 (1932).

48. See criticism of this dogma in HARPER, TORTS (I933) 488.

49. Holmes, J., dissenting in Plant v. Woods, I76 Mass. 492, 505, $57 \mathrm{~N}$. E. IoIr, I0I6 (rgoo) ; Brandeis, J., dissenting in Hitchman Coal \& Coke Co. v. Mitchell, 245 U. S. 229, 268 (I917). For a good discussion of the advantages to both employer and employees of the closed shop see Estey, The Labor Problmi (I928) 78 et seq. See also Berman, Labor AND THE SHERIAN ACT (1930) 246 et seq.

50. See Berry v. Donovan, I88 Mass: 353, 359, 74 N. E. 603,606 (1905); Elkind \& Sons v. Retail Clerks' Ass'n, I14 N. J. Eq. 586, 591, I69 Atl. 494, 496 (1933). 
under a closed shop only union members may be employed, membership in the union becomes a prerequisite of employment, and the power to admit or exclude becomes the power to grant or deny the opportunity for work of the type controlled by the union. ${ }^{51}$

Conceding that the evils which attend the closed shop are not to be lightly regarded, it does seem that the law could eliminate the evils to a considerable extent and yet permit labor combinations to impose the closed shop on employers. A closer inquiry into the facts of each particular case might enable the courts to remedy injustice to individual workers without resorting to a sweeping condemnation of the closed shop. For example, in Connors $v$. Connolly ${ }^{52}$ the plaintiff had been an employee and a member of the union which had closed-shop agreements with a number of employers. Plaintiff was ejected from the union because he would not pay an assessment, and his reason for not paying it was that the union owed him more than the amount of the assessment in the form of strike benefits which had accrued during a previous strike. When his fellow employees threatened to quit if plaintiff's employment continued, he was discharged, and recovered in a suit for damages against individuals participating in the action against him. The reasoning of the court was that since the defendants' action was directed toward the maintenance of the closed shop it was wrongful. Even if the result of the case is accepted, it would appear to be sufficient ground for giving plaintiff relief that he was unfairly excluded from the union and hence from a job, without basing the case on the supposed undesirability of the closed shop. ${ }^{53}$ The same criticism may be directed against the method of decision in cases where the employee against whom the labor action is directed desires to join the union but is refused admittance, ${ }^{54}$ or where the real purpose of the union is to punish plaintiff for alleged misconduct, ${ }^{55}$ or where plaintiff has what might be termed a justifiable reason for refusing to join the union. ${ }^{56}$ Another and perhaps more effective method of striking a middle ground between permitting and forbidding all action for a closed shop is legislation regulating labor unions, especially their powers to admit, exclude, and expel members. ${ }^{57}$

It has been suggested that a distinction should be made between efforts of unions to secure a closed shop in a single plant or limited locality and

51. See Cummins, The Labor Problem in the United States (1932) 313.

52. 86 Conn. 64I, 86 Atl. 600 (I9I3).

53. This method of reasoning was apparently followed in Brennan v. Hatters' Union, 73 N. J. Eq. 729, 65 Atl. I65 (I906); see also Blanchard v. Newark Council, 77 N. J. L. 389, 7I At1. I13I (I909).

54. Lucke v. Clothing Cutters, 77 Md. 396, 26 Atl. 505 (1893); Smith v. Bowen, 232 Mass. I06, I21 N. E. 814 (I919); see Shinsky v. O'Neil, 232 Mass. 99, 104, I2I N. E. 790, 792 (I919).

55. Cf. Shinsky v. Tracey, 226 Mass. 2I, II4 N. E. 957 (I9I7).

56. Sutton v. Workmeister, I64 I11. App. IO5 (IgII) (plaintiff would lose valuable old age benefits if he joined another union); Valentine v. Hyde, [I9I9] $2 \mathrm{Ch}$. I29 (similar situation).

57. See Estey, The Labor Probleim (Ig28) 86. 
activity to establish the closed shop throughout a wide area. ${ }^{58}$ The former does not operate either to deprive non-union workers of employment or to subject employers to union control in so drastic a fashion as the latter, and so the one may be permitted ${ }^{59}$ while the other is condemned. ${ }^{60}$ It is difficult to see the force of this contention. A worker who has an equal opportunity with all other workmen to join the union and who receives equal treatment from the union is not injured by the closed shop arrangement, no matter how wide the area in which it is established. If a workman is injured by unfair treatment the problem is not changed in kind from that discussed previously, and the remedies suggested are likewise applicable. ${ }^{61}$ From the employer's point of view a closed shop in his plant alone may be more disadvantageous than a closed shop throughout a large area or in the entire industry, since in the former case he may suffer a competitive handicap which is not present when a large part or all of the industry is organized. It would seem to be the better part of social wisdom to make no distinction based upon the extent to which the closed shop is sought throughout a community or industry, and to deal by legislation or decision with dangers that may lurk in monopoly and excessive power when they actually present themselves. ${ }^{62}$

\section{b. Concessions Short of Closed Shop}

A number of cases have arisen in which the labor activity is undertaken by a union with the object of strengthening its position as an organization, but in which it does not appear that the desire of the union is to limit employment to its own members. Courts are much more favorable to this type of action than to action for a closed shop. Included in this class are cases in which the demand of the union is that the employer cease discriminating against union workmen in respect to employment, either occasionally, ${ }^{63}$ or in pursuance of a consistent policy of exclusion (closed non-union shop).$^{64}$ In these cases the labor action was permitted.

Labor activity carried' on for the purpose of compelling the employer to refrain from requiring employees to agree not to join a union has been per-

58. See Connors v. Connolly, 86 Conn. 64r, 65I, 86 Atl. 600, 605 (xgr3); Jacobs v. Cohen, 183 N. Y. 207, 212, 76 N. E. 5.7 (1905); MASON, ORGANIZEd LABOR AND THE LAW (I925) 79, n.; Note (IgII) 59 U. OF PA. L. REv. 340.

59. National Protective Ass'n v. Cumming, I7o N. Y. 3I5, 63 N. E. 369 (I902); cf. Jacobs v. Cohen, 183 N. Y. 207,76 N. E. 5 (1905).

6o. Connors v. Connolly, 86 Conn. 641, 86 Atl. 600 (1913) ; Curran v. Galen, I52 N. Y. 33,46 N. E. 297 (1897).

6r. See Des Moines City Ry. v. Amalgamated Ass'n of Railway Employees, 204 Iowa II95, I206, 213 N. W. 264,269 (I927).

62. See Note (Ig2I) 3I YALE L. J. 86, 88.

63. Grant Construction Co. v. St. Paul Building Trades Council, I36 Minn. 167, I6I N. W. 520 (rgr7).

64. Gill Engraving Co. v. Doerr, 214 Fed. III (S. D. N. Y. I9I4) ; United Chain Theatres v. Philadelphia Motion Picture Operators' Union, 50 F. (2d) I89 (E. D. Pa. I93I); Restful Slipper Co. v. United Shoe \& Leather Union, II6 N. J. Eq. 52I, I74 Atl. 543 (1934); Wise Shoe Co. v. Lowenthal, 266 N. Y. 264, I94 N. E. 749 (I935); cf. Kirmse v. Adler, 3II Pa. 78, I66 Atl. 566 (1933) (dispute concerned hiring of union men at union wages). 
mitted. ${ }^{65}$ The same result has been reached where the purpose was to compel the employer to abandon individual bargaining and to deal with the union as representing the employees. ${ }^{68}$ Efforts of the union to recruit members by persuasion of non-union employees have been allowed, even though there was no existing dispute between the employees and the employer. ${ }^{67}$ Where, however, activity for the same purpose consisted of procuring the discharge of recalcitrant employees, an injunction was issued. ${ }^{68}$

\section{Discharge of Employee}

(For purposes other than to limit employment to union members)

Pursuing the prima facie theory of tort in this situation, the courts, in determining the question of justification, generally look to the reason for which the discharge is desired. If the continued employment of a workman is subversive of the interest of the employees as a laboring group and he is not the victim of unfair discrimination by the group, action to secure his discharge should be permitted; but if there is no reasonable connection between his discharge and the advancement of the group's status, the court should intervene. This conclusion is in accordance with the basic principle underlying all cases of labor action, namely that the interest of employees in the pecuniary value of their jobs and the conditions of their work is an interest which they may protect and further by their own action. The few cases in this category indicate that the courts have followed this principle. Where the object of procuring the discharge was to prevent a practice by one employee which resulted in giving him more work than the others, the court held that the plaintiff was not entitled to relief. ${ }^{69}$ Likewise, where the plaintiff's discharge was the result of his expulsion from the union because he made false charges against the officers, thus tending to disrupt the organization, an injunction was denied against interference with his employment. ${ }^{70}$ On the other hand, the fact that his co-workers personally disliked the plaintiff and this prompted the action against him was held not to relieve them of liability for causing the loss of his job. ${ }^{71}$ Liability has allso been imposed where the motive was to compel the payment of an alleged debt. ${ }^{\mathbf{2}}$

65. La France Co. v. International Brotherhood, I08 Ohio St. 61, I40 N. E. 899 (1923).

66. International Pocketbook Workers v. Orlove, I58 Md. 496, I48 Atl. 826 (1930); Steffes v. Motion Picture Operators' Union, I36 Minn. 200, I6I N. W. 524 (I9I7). (1920).

67. Diamond Block Coal Co. v. United Mine Workers, I88 Ky. 477, 222 S. W. Io79

68. Plant v. Woods, 176 Mass. 492, 57 N. E. IOII (I900).

69. Minasian v. Osborne, 210 Mass. 250, 96 N. E. I036 (I9II); see also Order of Railway Conductors v. Jones, 78 Colo. 80,239 Pac. 882 (I925).

70. Wolstenholme v. Ariss, [1920] 2 Ch. 403.

71. De Minico v. Craig., 207 Mass. 593, 94 N. E. 3I7 (I9rr) ; Bausbach v. Reiff, 244 Pa. 559, 91 Atl. 224 (I9I4). Dicta in these cases indicate that if the objectionable employee were unfit to work with ordinary workmen, because of temperament, lack of skill, etc., his fellow workmen would be justified in procuring his discharge.

72. Giblan v. National Amalgamated Union, [1903] 2 K. B. 600. 


\section{Employment, Reinstatement, and Continued Employment}

In an early nisi prius case it was held that the effort of a group of workmen to compel an employer by strike to retain a certain employee constituted a criminal conspiracy-apparently without any regard to the justness of his discharge. ${ }^{73}$ This point of view, that the mere fact that the concession demanded of the employer is the retention or reinstatement of a worker renders the labor action directed to that end unlawful, still persists in at least one jurisdiction. ${ }^{7}$ Here, as in the closed shop cases, the theory is that the end desired brings no immediate benefit to the workmen and so the interference with the employer's business is unjustified. No consideration is given to the advantage gained by the workmen in curbing the arbitrary exercise of the employer's power to discharge, thus securing themselves in their own jobs. If this gain is "remote" it is nonetheless real, and may be more important to workmen than an increase of wages. It would seem that this consideration should at least prompt the court to inquire into the reasonableness of the employer's act in discharging the worker. This technique has apparently been adopted by a number of courts in cases involving action to compel reinstatement of a discharged worker. ${ }^{75}$

A closely related factual situation is that where the demand of the union is for the continuance of a department of the employer's plant which he wishes to abandon, with consequent loss of employment for the workmen in that department. It has been held that labor action for this purpose may be enjoined. ${ }^{76}$ Another related type of case is that in which the demand is that a certain minimum number of persons be employed on some project. The usual case is that of a musicians' union which insists upon an orchestra of a specified number for theatrical performances. The cases differ as to whether such a demand may lawfully be enforced by labor action. ${ }^{77}$

\section{Payment of Money}

With virtual unanimity, the courts condemn labor action which has for its object the collection of money from the employer or an employee. Where

73. Commonwealth v. Curren, 3 Pitts. L. J. I43 ( $\mathrm{Pa} . \mathrm{Q}$. S. I869).

74. Mechanics Foundry Co. v. Lynch, 236 Mass. 504, I28 N. E. 877 (rg20).

75. Benito Rovira Co., Inc. v. Yampolsky, I87 N. Y. Supp. 894 (Sup. Ct. I92I) (employer refused to re-employ men not needed); Edelman, Inc. v. Retail Grocery Union, II9 Misc. 618, 198 N. Y. Supp. 17 (Sup. Ct. I922) (discharge for reasons of economy); Dubrow Pure Food, Inc. v. Glazel, 239 App. Div. 844,264 N. Y. Supp. 533 (2d Dep't, I932), 33 CoL. L. REv. I65 (1933) (discharge because of conversion of restaurant into cafeteria). In cases where the labor action was upheld the courts used the same reasoning. Wood Machine Co. v. Toohey, Ix4 Misc. I85, I86 N. Y. Supp. 95 (Sup. Ct. 1921) (discharge resulting from "discrimination"); United Chain Theatres v. Philadelphia Motion Picture Operators' Union, 50 F. (2d) I89 (E. D. Pa. I93r) (discharge because of union affiliation and insistence on union wages). Contra: Moreland Theatres Corp. v. Portland Motion Picture Operators' Union, I40 Ore. 35, I2 P. (2d) 333 (I932).

76. Welinsky v. Hillman, I85 N. Y. Supp. 257 (Sup. Ct. 1920); Rutan Co. v. Local Union, 97 N. J. Eq. 77, 128 Atl. 622 (I925).

77. Allowing enforcement: Scott-Stafford Co. v. Minneapolis Musicians Ass'n, II8 Minn. 410,136 N. W. I092 (I912); Empire Theatre v. Cloke, 53 Mont. I83, I63 Pac. I07 (1917). Contra: Haverhill Strand Theatre v. Gillen, 229 Mass. 4I3, II8 N. E. 67I (I9I8). 
the object is the recovery of an alleged debt owed to the union by a member, labor activity to compel payment has been held actionable and subject to injunction, ${ }^{78}$ even at the suit of the employer. ${ }^{78}$ Although unexpressed, the feeling is apparently general among the courts that the compulsory recovery of money, even though legitimately due, is something which should not be left to self-help but should be achieved through judicial processes. ${ }^{80}$ The relative simplicity of the question as to the propriety of a claim for an amount of money, as compared with the question of workers' rights to more wages or to a closed shop, for example, indicates the merit of this position.

A more difficult problem is presented when the money demanded is in payment of a fine imposed by the union upon the employer or an employee. Here there is no actual debt and the money could probably not be recovered in a court of law. Where the assessment is imposed by union leaders for their personal profit there can be no doubt that activity to enforce payment should not be permitted; and it has been condemned as criminal conspiracy and extortion. ${ }^{81}$ Where, however, the fine is levied in a bona fide effort to discipline an employer who has acted in a manner detrimental (or thought to be detrimental) to the interests of the union and the workers, in order to deter him from future conduct of such nature, there is greater room for argument. The imposition of the fine may thus be viewed as one method of accomplishing a result (improvement of the workmen's status) which is socially desirable and which the courts have made the basis for what instances of judicial laissez-faire there are in labor cases. But there is another consideration in these cases of labor activity. The step from imposition of fines on the employer for actual transgressions upon the workers' interests to extortion and racketeering by labor leaders is such an easy one to take, and once taken is so detrimental to the cause of labor itself as well as to society, that it is probably a wiser policy to condemn all activity to collect such assessments. This has been the result of the cases. ${ }^{82}$

78. Giblan v. National Labourers' Union, [I903] 2 K. B. 600; cf. Dorchy v. Kansas, 272 U. S. 306 (I926).

79. Harvey v. Chapman, 226 Mass. I9I, II5 N. E. 304 (1917) (case also involved other factors: boycott, false statements).

8o. See Dorchy v. Kansas, 272 U. S. 306 (1926).

81. People v. Walsh, 322 Ill. 195, I53 N. E. 357 (I926); State v. Daiton, I34 Mo. App. 5I7, II4 S. W. II32 (I908); People v. Barondess, X35 N. Y. 649, 3 I N. E. 240 (I892).

82. Money paid by an employer to avert threatened labor action may be recovered back. March v. Bricklayers' Union, 79 Conn. 7, 63 Atl. 291 (rgo6) ; Carew v. Rutherford, I06 Mass. I (1870) ; Burke v. Fay, I28 Mo. App. 690, 107 S. W. 408 (1908) ; cf. Day v. Studebaker Co., I3 Misc. 320,34 N. Y. Supp. 463 (N. Y. City Ct. I895) (employee compelled to pay employer a disputed claim by threat of discharge could not recover it back). See also Brennan v. United Hatters, 73 N. J. L. 729, 65 Atl. I65 (I906) (worker, discharged at behest of union because he had refused to pay fine assessed against him, may recover damages from the union). 
This universal condemnation of labor activity to collect money may at first glance seem difficult to reconcile with the substantial authority upholding the privilege of combinations of tradesmen to inflict economic damage in order to compel the payment of money. These cases involve the concerted refusal of associated tradesmen to deal with persons who owe debts to one of their number, in order to force payment; such action has been upheld. ${ }^{83}$ It is submitted that these cases are distinguishable from the labor decisions. It is among the normal functions of tradesmen to collect debts arising from their business (in a real sense it is one of their principal functions), and an association of tradesmen organized to promote the interests of its members may equally be said to have this as one of its normal activities. On the other hand, taking the analogous situation in the case of labor activity, it cannot be properly said to be the normal function of a labor union to collect debts for its members. Logically, one type of debt should be excepted-a debt for wages. Since it is the office of labor unions to advance and protect the interests of laborers as such, the collection of wage debts should be within its sphere of action, and activity to compel payment of such debts should be permitted. In one recent case this result was reached, although the court made no special point of the fact that the object of the union activity was to compel payment of a wage claim. ${ }^{84}$

\section{Appropriation of Work to One Group of Workmen to Detriment of} Competing Group

In the cases in which the real controversy is not between employer and employee but between competing groups of employees who seek by pressure upon the employer to compel him to favor one group over the other, the courts are surprisingly averse to judicial interference. There are two types of situations involving competition between laboring groups: one where workmen of different trades aspire to the same type of work; the other where each of two organizations (unions) whose members follow the same calling desires the work for its members to the exclusion of the other's members.

In the first situation it has been held that labor action will not be condemned. ${ }^{85}$ Since this result has been reached in Massachusetts, a notoriously "anti-labor" jurisdiction and also one whose decisions in labor cases have been widely followed, it seems safe to say that this result will be accepted

83. Ulery v. Chicago Livestock Exchange, 54 I1l. App. 233 (I894) ; Brewster v. Miller, IOI Ky. 368, 4r S. W. 30r (1897).

84. Du Roy v. Gillmore, 246 App. Div. 37, 284 N. Y. Supp. 385 (Ist Dep't, 1935).

85. Pickett v. Walsh, 192 Mass. 572, 78 N. E. 753 (1906). But see Armstrong Cork \& Insulation Co. v. Walsh, 276 Mass. 263 , I77 N. E. 2 (I93I); cf. Allen v. Flood, [I898] A. C. I. 
generally. Most of the cases of the second type, involving a contest between rival unions, adopt the attitude of non-interference. ${ }^{86}$

\section{Labor Action Involving Breach of Contract}

The cases in which a significant factor is the existence of some contract which will be broken as the result of the labor action may be divided into two categories: (I) where the contract is between the employer and the workmen taking the action (or a union); (2) where the contract is between the employer and a third person.

In the first situation labor action is generally condemned and will be enjoined. ${ }^{87}$ The result in these cases seems proper. If the workmen or their representatives have agreed with their employer upon certain conditions of work, it seems just that the courts should afford relief to the employer against violation of such an agreement, at least in the absence of other factors, such as a showing that the contract in question was unfairly imposed upon the workers by the employer. Moreover, if employees may with virtual impunity break contracts entered into for the purpose of settling labor difficulties the employer will be very slow to negotiate such agreements and the amicable settlement of labor controversies will be discouraged. ${ }^{88}$

The second situation involves a modern application of the doctrine developed in the last century that inducing a person to break a contract with another may be the basis for an action. ${ }^{89}$ Where labor action involves the inducing or knowingly causing the breach of a contract, most courts readily employ this fact as a ground, either in itself or in conjunction with other facts, for interceding in favor of the employer. This is done apparently on the theory that such conduct is always and necessarily wrong, and without any consideration of the possible existence of justifying circumstances.

A type of contract often involved in these cases is that between an employer and his employees providing that the latter will not join a labor union, commonly known as a "yellow dog" contract. In nearly all of these cases the courts have enjoined the labor action, basing the decision at least

86. Reform Club v. Laborers' Union, 29 Misc. 247, 6o N. Y. Supp. 388 (Sup. Ct. I899) (injunction suit by union) ; J. H. \& S. Theatres, Inc. v. Fay, $260 \mathrm{~N}$. Y. 315, I83 N. E. 509 (I932). This result is criticized in Note (I932) 46 HARv. L. Rev. I25.

87. Barnes v. Berry, I56 Fed. 72 (S. D. Ohio, I907) ; Preble v. Architectural Workers' Union, 260 Ill. App. 435 (I93I) ; Meltzer v. Kaminer, I3I Misc. 813, 227 N. Y. Supp. 459 (Sup. Ct. 1927). But $c f$. Lundoff-Bicknell Co. v. Smith, 24 Ohio App. 294, I56 N. E. 243 (1927).

88. In the reversed situation-where the union seeks to enjoin an employer from action involving breach of a contract with the union-the same result has been reached. Mississippi Theatres v. Hattiesburg Local Union, I74 Miss. 439, I64 So. 887 (I936) ; Goldman v. Cohen, 222 App. Div. 631, 227 N. Y. Supp. 3Ir (Ist Dep't, I928) ; Harper v. Local Union, 48 S. W. (2d) 1033 (Tex. Civ. App. r932).

89. See Sayre, Inducing Breach of Contract (1923) 36 HARv. L. Rev. 663. 
partly on the fact that the action would cause a breach of the contract. ${ }^{90}$ In New York a contrary position has apparently been taken in recent cases. ${ }^{91}$

In a number of cases the contract involved was between the employer and his customer, the pressure of the labor action being brought to bear upon the latter to induce him to cease dealing with the employer. In nearly all these cases the labor activity was condemned. ${ }^{92}$ When the contract involved is of employment for a definite time, labor action directed toward a breach of such contract by inducing employees to quit is universally held wrongful and is enjoined. ${ }^{93}$

Another type of contract is that between the employer and a union for the supply of workmen, and the labor action is by a rival union which seeks to displace the first. Cases involving such facts have arisen in New York, and the presence of the contract has not moved the courts to restrain the action of the rival unions; ${ }^{94}$ but an opposite result has been reached in Massachusetts. ${ }^{95}$ The New York courts and a few others apparently reject the notion that any labor activity which causes a breach of contract is perforce unlawful, and recognize that if the interest of the workmen is strong enough they may, to further that interest, even cause breaches of contractual relations. ${ }^{96}$

On principle it would seem that a distinction should be drawn between contracts which the employer makes in the ordinary course of his business,

9o. International Organization, United Mine Workers of America v. Red Jacket Consolidated Coal \& Coke Co., I8 F. (2d) 839 (C. C. A. 4th, 1927), cert. denied, 275 U. S. 536 (I927) ; Flaccus v. Smith, I99 Pa. I28, 48 Atl. 894 (I90I) ; Kraemer Hosiery Co. v. American Fed. of Full Fashioned Hosiery Workers, 305 Pa. 206, I57 Atl. 588 (I93I); cf. Hitchman Coal \& Coke Co. v. Mitchell, 245 U. S. 229 (I9I7). Supposedly the leading case on this point, doubt has since been expressed as to whether the breach of contract feature was the real basis of the decision. See American Steel Foundries v. Tri-City Central Trades Council, 257 U. S. I84, 211 (I92I). Witte mentions 60 injunctions (mostly unreported officially) against inducing breach of yellow dog contracts. Witte, The Governarent IN LABOR DisPUTES (1932) 224.

9r. Interborough Rapid Transit Co. v. Lavin, 247 N. Y. 65 , I59 N. E. 863 (1928) ; Interborough Rapid Transit Co. v. Green, I3I Misc. 682, 227 N. Y. Supp. 258 (Sup. Ct. I928). See Carey and Oliphant, The Present Status of the Hitchman Case (1929) 29 CoL. L. REv. 441, 453-460.

92. $\mathrm{R}$ an W Hat Shop, Inc. v. Sculley, 98 Conn. I, Ir8 Atl. 55 (1922); Service Wood Heel Co. v. Mackesy, 199 N. E. 400 (Mass. 1936); Beattie v. Callanan, 82 App. Div. 7, 8I N. Y. Supp. 413 (Ist Dep't, 1903) ; Parker Paint Co. v. Local Union, 87 W. Va. 63I, I05 S. E. 91 I (I92I). Contra: Parkinson Co. v. Building Trades Council, I54 Cal. 58I, 98 Pac. 1027 (1908). See Note (I922) 32 Y ALE L. J. I7I. In one interesting case in which an injunction was denied against inducement of breach of customer contracts, the court stressed the fact that the union was attempting to remedy a condition of employment which tended to degrade the morals of employees. Brimelow v. Casson, [I924] I Ch. 302.

93. Rice, Barton \& Fales Co. v. Willard, 242 Mass. 566, 136 N. E. 629 (1922) ; VailBallou Press, Inc. v. Casey, I25 Misc. 689, 212 N. Y. Supp. I13 (Sup. Ct. 1925) ; South Wales Miners' Fed. v. Glamorgan Coal Co., [Ig05] A. C. 239 (action for damages).

94. Stillwell Theatre v. Kaplan, 259 N. Y. 405 , I82 N. E. 63 (1932) ; J. H. \& S. Theatres, Inc. v. Fay, 260 N. Y. 315, 183 N. E. 509 (1932).

95. Goyette v. Watson Co., 245 Mass. 577, I40 N. E. 285 (I923).

96. See Exchange Bakery v. Rifkin, 245 N. Y. 260, 266, I57 N. E. I30, I34 (1927). See also Parkinson Co. v. Building Trades Council, I54 Cal. 581, 602, 98 Pac. I027, 1036 (I908). Cf. Brimelow v. Casson, [1924] I Ch. 302. 
which are primarily intended to advance and secure his position as an entrepreneur, and contracts which he makes for the primary purpose of combating labor activity and organization, which he uses purely as weapons in the industrial contest. Contracts of the first type should be protected against interference by third parties to the same extent as other commercial contracts. ${ }^{97}$ An entrepreneur who seeks the security of binding contractual relations with his customers, suppliers, or employees, in order to assure for the future a reliable source of the means of carrying on his business, should perhaps be entitled to almost complete protection against interference with such relations by others, at least where the interest of the latter is no greater than that of ordinary competitors. ${ }^{98}$ Where the contract involved, however, is not a normal business agreement, but is used primarily as a weapon against organized labor, the rationale underlying the protection of business contracts is not applicable. An employer does not enter into a contract with his employees that they will not join a union in order to render secure his supply of labor. Ordinarily such a contract does not, in terms, prevent the quitting of employment at any time; all that is prevented is joining a union. It is true that such $a_{1}$ contract may be an aid in preventing or forestalling strikes, and in that sense advances the security of the employer's business; but even this result cannot be said to be the real object of the employer in exacting these contracts. Their real purpose is to weaken labor organization by imposing legal and moral checks upon the affiliation of employees with unions, and by giving employers a "talking point" in the law courts against union activity. ${ }^{99}$

It is submitted that the courts have erred in emphasizing the contractual aspect of these agreements instead of their aspect as weapons in the industrial struggle, and in applying to them the same theory which has been used to condemn conduct inducing breach of ordinary business contracts. Being simply a device to combat the interests of organized labor, these contracts should receive no more protection against interference by the forces of labor than any other such device-that is, the fact that the common law elements of contract are present should be of no legal significance in so far as non-parties are concerned.

97. Conduct of entrepreneurs inducing breach of contract of a competitor is generally held unlawful, even though the purpose of the activity is to advance the business interests of the actors. E. g., Northern Wisconsin Co-operative Tobacco Pool v. Bekkedal, 182 Wis. 57I, 197 N. W. 936 (I923) ; Peekskill Theatre, Inc. v. Advance Theatrical Co., 206 App. Div. I38, $200 \mathrm{~N}$. Y. Supp. 726 (Ist Dep't, 1923). The attempt of an employers' association to cause its members to break contracts with a union respecting conditions of work has been enjoined. Schlesinger v. Quinto, 20I App. Div. 487, I94 N. Y. Supp. 40I (Ist Dep't, I922).

98. Cf. Quinlivan v. Brown Oil Co., 96 Mont. I47, 29 P. (2d) 374 (I934); Knapp v. Penfield, I43 Misc. 132, 256 N. X. Supp. 4I (Sup. Ct. I932) (both cases in which inducing breach of trade contracts was allowed, the circumstances being unusual).

99. After the Hitchman decision, the use of yellow dog contracts by employers greatly increased. See Witte, The Government in Labor Disputes (1932) 221 ; Carey and Oliphant, The Present Status of the Hitchman Case (1929) 29 CoL. L. REv. 44I. 
IV. Labor Action by Persons Not Employees or Representatives of Employees of the Employer Affected

In dealing with cases of labor action against an employer, the courts with few exceptions have evidently proceeded upon the theory that the privilege of conducting such activity, where it exists at all, is a privilege of employees of the particular business unit involved, or at most of their appointed representatives-including in the term "employees" persons who have quit or been discharged and are conducting the activity in order to regain their places $^{100}$ or to secure some advantage connected with their work. ${ }^{101}$ The fact that the persons carrying on the activity are "outsiders" has been a significant element in cases in which the action is conducted by a union not recognized by the employer and not including in its membership any employees of the business. This fact has been stressed by many courts and has provided wholly or partly the basis for decisions condemning the labor action, even where the "outsiders" were representatives of a labor union seeking to compel the employer to deal with it. ${ }^{102}$

In this situation the New York courts are once more almost alone against the field. In a number of cases the court has refused to enjoin the labor action (except as to a few specific types of conduct) in spite of the presence of the fact that the activity was instituted and carried on by "outside unions". ${ }^{103}$ In Ohio and Minnesota similar holdings exist, ${ }^{104}$ while a dictum in a recent Pennsylvania case indicates a similar opinion. ${ }^{105}$

The hesitancy of courts to permit the use of economic pressure against an employer by unions which do not represent the particular employees at the plant is evidently the result of a judicial reluctance to accept as socially tolerable the principle of trade unionism. It is a generally accepted fact that unions cannot hope to gain sufficient strength for the economic contest with the employer unless their organization extends beyond the limits of indi-

100. United Chain Theatres v. Philadelphia Motion Picture Operators' Union, 50 F. (2d) 189 (E. D. Pa. I93I).

ror. Cf. Steinert \& Sons Co. v. Tagen, 207 Mass. 394, 93 N. E. 584 (IgII).

102. Hitchman Coal \& Coke Co. v. Mitchell, 245 U. S. 229 (I9I7) ; Alco-Zander Co. v. Amalgamated Clothing Workers, 35 F. (2d) 203 (E. D. Pa. 1929); Keith Theatre Co., Inc. v. Vachon, I87 Atl. 692 (Me. 1936); Market Street Corp. v. Delicatessen Workers, I79 Atl. 689 (N. J. Eq. 1935) ; Crouch v. Central Labor Council, I34 Ore. 6I2, 293 Pac. 729 (I930). This factor has even been relied upon when the union included some employees in its membership. Elkind \& Sons v. Retail Clerks' Ass'n, II4 N. J. Eq. 586, I69 Atl. 494 (I933); cf. Montgomery v. Pacific Ry., 293 Fed. 680 (C. C. A. gth, I923). "Outside union" action has even been enjoined in face of the federal statute prohibiting injunctions in situations which would seem to include this type of activity. Lauf v. Shinner Co., I Prentice-Hall 1936 Labor Serv. $\int 18116$ (C. C. A. 7th, 1936).

103. Interborough Rapid Transit Co. v. Lavin, 247 N. Y. 65 , I59 N. E. 863 (I928); Wise Shoe Co. v. Lowenthal, 266 N. Y. 264, I94 N. E. 749 (I935).

I04. Steffes v. Motion Picture Operators' Union, I36 Minn. 200, 6I N. W. 524 (I917); Clark Lunch Co. v. Cleveland Waiters' Local Union, 22 Ohio App. 265, I54 N. E. 362 (I926). 105. See Kraemer Hosiery Co. v. American Fed. of Full Fashioned Hosiery Workers, $305 \mathrm{~Pa}$. 206, 215, I57 Atl. 588, 59 I (I93I). 
vidual business units. ${ }^{106}$ If a union's membership and influence are limited to the employees of a single plant, the workmen's position is ordinarily little more advantageous than if there were no union at all and bargaining were done on an entirely individual basis. Unless the work is of a highly skilled nature or for some other reason there is an abnormal scarcity of the type of labor involved, the employer can with ease draw his labor from other sources when his workmen protest their conditions of employment. This is doubtless one of the chief reasons for the efforts of unions to extend their influence throughout an entire economic area or a whole industry.

Another reason that may impel a union to seek recognition from nonunion employers is that the latter, because of their ability to deal individually with their employees, may enjoy material competitive advantages over other employers in the industry who are unionized. The result of such a situation is that the organized workers may find it more difficult to obtain concessions from the union employers. The latter may even be compelled to abandon their union policy or go out of business. In any event the competition of the non-union employers is definitely destructive to the interests of the organized workers. ${ }^{107}$

It is thus obvious that labor activity by persons unconnected with the business unit involved may be motivated by a desire to further or protect the interests as workmen both of the employees of the plant and of the workers of the industry generally. These interests are precisely like those which courts recognize in other situations as providing a basis for immunity from judicial interference with the use of economic pressure. Certainly it is inaccurate, if not worse, to describe the representatives of "outside unions" as "intermeddlers". ${ }^{108}$ If the device of labor organization is accepted as a proper means of advancing the economic position of laborers, the fact that activity is conducted by a union against an employer none of whose employees is a present member of the union should have very little weight in deciding the propriety of the activity.

\section{Relation of the Plaintiff to the Controversy}

In determining the result of a case in which the legality of labor action is brought into question, a material consideration may be the position which

106. See American Steel Foundries v. Tri-City Central Trades Council, 257 U. S. I84, 209 (I921) ; Berman, Labor and the Sherman ACr (1930) 249.

107. In Alco-Zander Co. v. Amalgamated Clothing Workers, 35 F. (2d) 203 (E. D. Pa. 1929), the union, seeking recognition by Philadelphia manufacturers, endeavored to show that the low-wage scale of the latter's plants enabled them to enjoy such an advantage over New York manufacturers, all of whom were unionized, that the union wage-scale in New York was seriously threatened. The court, enjoining the union activity, refused to give weight to these facts. A similar contention was made and rejected in the Hitchman case, $245 \mathrm{U}$. S. 229 (I9I7).

108. See Bayonne Textile Corp. v. American Fed. of Silk Workers, II4 N. J. Eq. 307, 3I7, r68 At1. 799, 803 (1933). 
the plaintiff occupies in the industrial controversy. Leaving aside criminal prosecutions, suits against workmen are brought, generally, by three classes of persons: employer, employee (past, present, or prospective), and third persons who are affected by the labor activity. The great majority of cases are those in which the plaintiff is the employer against whom the grievance lies. Most of the suits brought by employees are those resulting from their discharge or threatened discharge demanded by the workmen. The few cases in which persons other than these sue arise in the situation where labor action is directed at such persons in order to bring pressure to bear through them upon the employer.

A situation in which it obviously makes a difference who brings suit involves the inducement of the employer by mere persuasion to discharge an employee. It is hardly likely that the employer can make out any cause of action in such case; yet the employee may well be entitled to relief. ${ }^{109}$ When the employer has a closed shop contract with the union, activity to enforce compliance affords no cause of action to the employer; ${ }^{110}$ but if the activity takes the form of causing the discharge of a particular non-union worker, the latter may be entitled to maintain suit. ${ }^{111}$ Even where there is no agreement for a closed shop, there are rational grounds for making a distinction between actions brought by the employer and those by an employee affected by labor activity directed toward the establishment of a closed shop. The principal argument in favor of judicial interference with efforts for this purpose is that the closed shop tends to place in the hands of unions a dangerous power which may lead to unfair discriminations among workers seeking employment. It may well be contended that this is no special concern of the employer, and that the court's aid should be extended only to workmen who suffer specific injury. It should be noted, however, that no court has made this distinction; those courts which forbid labor action for this purpose allow both employer and employee to maintain suit. ${ }^{112}$

A similar point may be made in regard to cases in which the labor action involves third persons. In nearly all these cases the plaintiff is the employer, not the third parties directly affected. A court might be well justified in rejecting a suit by the employer, yet entertaining one by the third party. Here again, however, there is virtually no intimation of such a distinction in the cases. In the few cases in which suit was brought by the third party

I09. E. g., Order of Railway Conductors v. Jones, 78 Colo. 8o, 239 Pac. 882 (I925); Eschman v. Huebner, 226 IIl. App. 537 (r922).

IIo. Greenfield v. Central Labor Council, I04 Ore. 236, I92 Pac. 783 (1920).

III. Sutton v. Workmeister, I64 Ill. App. 105 (I9II) ; Shinsky v. Tracey, 226 Mass. 2I, II4 N. E. 957 (I9I7). But cf. Shinsky v. O'Neil, 232 Mass. 99, I21 N. E. 790 (I919); Reihing v. Local Union, 94 N. J. Eq. 240, 109 Atl. 367 (1920).

II2. See cases cited supra notes 45 and 46. 
he was granted relief, ${ }^{113}$ with one exception ${ }^{114}$ but in none did the court indicate that a different result might follow if the employer were the plaintiff. In one case in which the employer sued, the court, in denying relief, hinted vaguely that not the plaintiff, but the third party, had cause for complaint. ${ }^{115}$

\section{Conclusions}

It has not been the purpose of this study to suggest specific solutions for the legal problems arising from the efforts of workmen to improve their conditions of employment. In fact, one of the results of the investigation is a conviction that such solutions cannot successfully be achieved without a study and analysis of far more material than has been covered. For example, a proper appraisal of the fact that the object of labor action is to establish a closed shop requires a knowledge of the actual practices of unions in admitting and excluding members, so that the amount of discrimination against non-union workmen can be determined. The materials for a practical solution of the "boycott" problem should include statistics of the effect of indirect pressure upon the business of the community; and, in order to determine whether workmen need such a drastic weapon, it is necessary to have knowledge of the exact nature and extent of the employer's economic power insofar as it may be used to coerce workers to accept the employer's terms. An understanding of these economic and social phenomena requires a detailed factual study such as is not attempted here.

Because of the undeveloped state of the law upon this subject few generalizations may safely be made as to the results of the decisions. In studies of controversial fields of the law it is fashionable to say that there is a "hopeless conflict" of judicial opinion; and the observation cannot be escaped here. On one of the chief questions-the legality of action for a closed shop-there is a definite jurisdictional split. ${ }^{116}$ Even within a single jurisdiction it is sometimes difficult to determine the position of the courts. ${ }^{117}$

II3. Thomas v. Cincinnati R. R., 62 Fed. 803 (S. D. Ohio, I894) ; Bricklayers' Union v. Ruff, I60 Md. 483, r54 Atl. 52 (I93I) ; Burnham v. Dowd, 2I7 Mass. 35I, I04 N. E. 84I (I9r4) ; Pacific Typesetting Co. v. International Typographical Union, I25 Wash. 273, 216 Pac. 358 (I923).

II4. Ruff \& Sons v. Bricklayers' Union, I63 Md. 687, 164 Atl. 752 (I933). (x933).

II5. See Zaat v. Building Trades Council, I72 Wash. 445, 449, 20 P. (2d) 589, 59I

II6. See cases cited supra notes $42-46$.

II7. New Jersey chancellors have consistently held that the closed shop is an improper object of labor activity. See cases cited supra notes 45,46 . But the Court of Errors and Appeals has upheld labor action for this purpose. Bayonne Textile Corp. v. American Fed. of Silk Workers, II4 N. J. Eq. 307, I72 Atl. 55I (1934). In Maryland there are apparently conflicting decisions: compare Blandford v. Duthie, 147 Md. 388, I28 Atl. I38 (1925) with Ruff \& Sons v. Bricklayers' Union, I63 Md. 687, I64 Atl. 752 (1933). In Illinois, Fenske Bros. v. Upholsterers Union, 358 IIl. 239, I93 N. E. II2 (I934), upholding the labor action, seemingly overrules Barnes v. Chicago Typographical Union, 232 Ill. 424,83 N. E. 940 (1908). 
There seems to be little disagreement, aside from the New York cases, as to the legal effect of labor action causing a breach of contract or action carried on by "outside" unions; both are grounds for condemning the activity. In the situation where pressure is exerted against third parties, the decided weight of authority is against the labor action; although the language of many of the cases is more sweeping than is justified by the actual results of the decisions.

In the analysis of the cases in this study factual distinctions have been suggested, not all of which are supported by authority, but which are based on grounds considered rational. The purpose of pointing out these distinctions has been partly to aid in the understanding of the cases and partly to suggest possible trends of future decisions, but especially to indicate what is thought a desirable method of treatment which most courts, if the reported opinions are a reliable guide, have neglected. Instead of examining the facts of the cases for possible differences which may justify or require varying legal results, courts persist in employing vague, often meaningless, concepts as a basis of decision. ${ }^{118}$ In few other fields of the law are the concepts so ill-defined and the "theories" and "doctrines" so little subjected to critical examination by the courts. The almost universal use of such terms as "strike", "boycott", and "secondary boycott" frequently obscures the issue. A court may condemn a "strike" for a certain purpose on the ground that previous cases had condemned a "strike" under similar circumstances, when a closer examination into the facts of the present case may reveal that the activity of the workmen consisted simply of a cessation of labor, whereas in the previous cases the activity included picketing or even acts of violence. ${ }^{119}$ Even greater confusion results from the use of "boycott"- "primary" and "secondary". The consequence of this unanalytical labelling is a failure to recognize the possibility of reaching varying legal conclusions as the facts of cases vary. Thus many courts are prone to decide a case by giving the fact situation a name (e. g., "secondary boycott") and then arriving at a result supposedly dictated by previous cases which had used the same name. ${ }^{120}$

A more fundamental criticism may be directed against the apparent attitude of courts in general toward the respective parties in the controversy. One cannot read many decisions on this subject without receiving the impression that the average court begins the consideration of a case with something

II8. Professor Sayre makes the same observation in Labor and the Courts (1930) 39 YaLE L. J. 682, 704. Cf. (I93I) 80 U. of PA. L. REv. 305. Even the "critical" writers are often satisfied with generalizations. See Mason, OrGanized Labor and tHe Law (I925) 82.

IIg. Compare cases cited supra notes I2 and I3.

I20. See Commercial Cleaning Co. v. Awerkin, I38 Misc. 512, 5I5, 240 N. Y. Supp. 797, 800 (Sup. Ct. I930) (". . . these activities complained of constitute an illegal secondary boycott, and the courts of this state have consistently maintained that a secondary boycott will not be tolerated"); Martin v. McFall, 65 N. J. Eq. 9I, 55 At1. 465 (I903) ("Another unlawful means . - is the boycott in its various forms. This, in whatever form it assumes, is unlawful"). 
akin to a prejudice in favor of the employer. This criticism is not directed at individual judges, but at the body of concepts and principles which comprise what may be called the "verbal law". The continued use of such terms as "intimidation" and "threats" to describe ordinary economic pressure, ${ }^{121}$ "conspiracy" in referring to combination of workmen, and "primary intention to injure" in speaking of objects of labor action, indicates a tendency to look with disfavor upon labor's cause before it is pleaded. The most concrete manifestation of this attitude is the persistence of the "prima facie" theory of tort applied in these cases-the theory that economic damage caused by labor activity is presumptively actionable, with the burden upon defendants to establish justification. It is a doctrine which has too long been accepted without criticism. It involves the assumption that the only interests concerned are, on the one hand, the desire of workmen to improve their status, and on the other the interest of the employer in being free to run his business without interference. The employer is looked upon as a passive party whose only role is as a target of injurious activity. But suppose that the employer has cut wages, or discharged a workman because of union affiliation; is this not affirmative action inflicting damage upon the workmen? Even if the employer has merely refused to grant a demanded concession, his refusal is as active as the refusal of employees to work. In short, it is unrealistic to regard an industrial dispute culminating in labor action as involving simply the infliction of injury by the workers upon the employer. It is a naive point of view that should have died with the Philadelphia Cordwainers' Case. ${ }^{122}$ Actually an industrial dispute is a manifestation of a larger conflict of interest between employer and workers, each side seeking to gain a greater share of the results of production to the detriment, if necessary, of the other. If the activity of the workers does not achieve its purpose and they fail to advance their interests, the employer is not merely saved the loss of business which the labor action would have occasioned; he actually makes an advance in his fundamental struggle with labor or at least maintains his former position. Consequently, when a court interferes in a labor dispute, as by enjoining the activity of the workmen, it does far more than prevent temporary damage to the employer; it renders him positive aid in the economic contest. In such a situation how can it be justly said that' one party or the other is presumptively wrong?

The primary concern of the courts should be to equalize the economic weapons at the command of both parties to the industrial contest. ${ }^{123}$ If the law interferes at all with the operation of "natural" economic forces, its

I2I. See dissenting opinion of Holmes, J., in Vegelahn v. Guntner, I67 Mass. 92, 107, 44 N. E. I077, 1087 (1896); Ware v. Motor Trade Ass'n, [1920] 125 L. T. R. (N. s.) 265, 272, 276 (C. A.), where the judge refers to the "vocabulary of vague vituperation".

122. Reported in Sayre, Cases on Labor Law (r923) 99.

123. See Note (1921) 31 YaLe L. J. 86, 87-89. 
purpose should be to prevent one side from having too great an advantage over the other. It may be suggested, with reason, that it is impossible for courts to maintain a balance of power between labor and employer in the abstract. Economic and social conditions, over which neither party to the contest has control, may make the problem of balancing their powers vary from industry to industry, locality to locality, and even in individual cases. Should a court consider these questions? No decision has ever been expressly based upon a consideration of such facts. It may be contended that an examination of the statistical material involved, even if it be conceded that the average court is equipped to study and utilize such facts, may take so much time that a labor controversy will be over, perhaps to the dissatisfaction of both parties, before a decision is reached. It is perhaps too much to expect of judges that they will or can make a detailed comparative study in each case of the size, strength, financial resources, and influence of each protagonist. But it is by no means impossible or too difficult to consider differences among industries and economic areas, and to vary the results of classes of cases with reference to these important variations of fact. 